\title{
Tumor Antigen-Based Immunotherapy and Immunoprevention of Cancer
}

\author{
Sean O. Ryan Kira R. Gantt Olivera J. Finn \\ Department of Immunology, University of Pittsburgh School of Medicine, Pittsburgh, Pa., USA
}

\section{Key Words}

Immunosurveillance $\cdot$ Neoplasms, experimental $\cdot$ Cancer vaccines · Adjuvants • MUC1 • Cyclin B1 • HER-2/neu • Carcinoembryonic antigen $\cdot$ NY-ESO-1

\begin{abstract}
Any approach to the treatment and prevention of cancer must face the daunting reality that each cancer may be as individual as the patient in whom it has evolved. The challenge is also to develop a therapy that would eradicate that which is abnormal while preserving what is normal. For many years, therapies have been sought that could target a specific abnormal cancerous processes, such as rapid division or increased vascular flow, but with only limited success. Unfortunately, these successes have also been accompanied by varying degrees of toxicity and there is currently no standard therapy that can eradicate clinical disease and prevent recurrence while leaving normal tissue unharmed. However, approaches directed towards manipulating tumor-specific immunity hold promise for effective treatment and lasting cure. These approaches are based on the exceptional specificity of the immune system, the potential for long-term protective memory, and the accumulated evidence that affected individuals have spontaneous immune responses against their own tumors.

Copyright ๑ 2007 S. Karger AG, Basel
\end{abstract}

\section{Introduction}

Vital to investigating the immune system's spontaneous responses to cancer as a basis for designing immunotherapy has been a resurgence in patient studies and animal models that support the immunosurveillance hypothesis. Proposed in 1970 by Burnet and Thomas, the term 'immunosurveillance' implies that many tumors occur but never progress to clinical disease because they are cleared naturally by the immune system [1]. This hypothesis postulates that cancer can overcome the individual response when it evolves to evade normal immune defenses, or when the immune system becomes compromised.

Immunosurveillance was difficult to test experimentally when originally proposed and remained primarily a hypothesis for many years. This was partly due to the lack of an appropriate mouse model. The evidence that the immune system suppresses tumor development became ultimately quite clear as differences between mouse strains were better understood and reagents that addressed the role of cytokines and other immune mediators became available [1]. For example, IFN $\gamma$ and perforin were shown to be necessary for tumor rejection in mice. When IFN $\gamma$ responses were eliminated, such as in IFN $\gamma$ receptor or STAT1-deficient mice, or with monoclonal blocking antibody to IFN $\gamma$, susceptibility to methylcholanthrene-induced tumors was increased. These same IFN $\gamma$-unresponsive mice crossed with p53 tumor

Correspondence to: Dr. Olivera J. Finn

Department of Immunology, University of Pittsburgh School of Medicine

E1040 Biomedical Sciences Tower

Pittsburgh, PA 15261 (USA)

Tel. +1 412648 9816, Fax +1 412648 7042, E-Mail ojfinn@pitt.edu 
suppressor-deficient mice showed an increase in tumor burden when compared to mice with p53 deficiency alone, implying that IFN $\gamma$ is necessary for continued protection against tumors. Perforin-deficient mice demonstrated a similar susceptibility to tumor formation compared to controls [1].

Spontaneous murine tumor models based on transgenes that carry known oncogenic mutations, such as Kras, INK4A and PTEN, are making it possible to determine what early steps in tumor development are subject to immunosurveillance $[2,3]$. The ability to time and examine early neoplasia in mice will allow an evaluation of which immune effector cells, cytokines, and other immune components are induced and necessary for eradication of transformed cells.

\section{Immune Response to Tumors}

With the acceptance of the immunosurveillance hypothesis it has become apparent that giving the immune system the appropriate stimulus will allow it to overcome evasion and eliminate tumors. Of course, by the time most patients are diagnosed with a malignancy, they have been harboring the tumor for some time and are usually immunosuppressed [4]. This is likely to be the reason that early detection and treatment of disease result in the best clinical prognosis as treatment occurs before immunosuppressive effects have developed fully $[5,6]$. Increasingly, solutions to the cancer problem are focused on immunoprevention at early stage immunotherapies (fig. 1). The most recent breakthrough in this regard is the multivalent vaccine against human papilloma virus that prevents viral infection and thus cervical cancer [7].

The immune responses that are most effective against tumor growth are those generated through a well-balanced and well-timed interplay between the innate and the adaptive immune system. Antigens are presented by activated dendritic cells (DCs) to CD4 T cells, which in turn coordinate CD8 cytotoxic T lymphocytes (CTL) and antibody production by B cells [8]. In some cases the contribution of activated NK and NKT cells, which like CTLs use perforin and granzymes to destroy their targets, have been shown to be necessary for tumor control $[9,10]$.

When the balance between the innate and the adaptive immunity is skewed in favor of innate immune responses, this can also exacerbate disease and facilitate tumor growth. Some components of the innate immune response found in tumors, such as macrophages and mast cells, have been correlated with increased tumor growth and metastasis [11, 12]. Upon activation, these cells release oxidants, prostaglandins, cytokines, and other components that directly and indirectly cause tissue destruction and remodeling. Peripheral granulocytes from patients with metastatic adenocarcinomas have been shown to release hydrogen peroxide which in turn impairs $\mathrm{T}$ cell function [4]. Tumor-infiltrating macrophages can secrete matrix metalloprotease-9 (MMP9) that releases VEGF from extracellular matrix stores, increasing angiogenesis at the tumor site and suppressing DC function [13].

Chronic inflammation, characterized by sustained activation of many players in the immune system, is suspected to drive premalignant lesions into fully malignant states. Inflammation can occur in response to chronic infections with a diverse array of pathogens such as hepatitis viruses or Helicobacter pylori [14]. Sustained inflammation can also be the result of an individual's inability to restore immune homeostasis after infection. The increased expression of COX-2, an enzyme in the prostaglandin biosynthetic pathway, has been correlated with colorectal cancer [15]. Similarly, blocking the function of this enzyme with nonsteroidal anti-inflammatory drugs has correlated with decreased cancer risk in humans, particularly in colon cancer [16]. Consequently, halting chronic inflammation may restore the immunosurveillance mechanisms necessary to control transformation and neoplastic growth.

In contrast to chronic inflammation, acute inflammation has been shown to eliminate some cancers. One current therapy based on the principle of eliciting strong acute inflammation uses bacillus Calmette-Guérin (BCG), an attenuated strain of Mycobacterium tuberculosis, to treat bladder cancer [17]. Intravesicular instillation of the bacterium into the bladder activates resident DCs, which then increases antigen presentation and cytokine production. The first immune-based therapy that used acute inflammation to fight against cancer was the administration of 'Coley's toxins'. William Coley had observed that patients with sarcomas that also suffered from erysipelas, a severe bacterial skin infection coupled with a fever, experienced remission of their tumors. Based on this evidence, he subsequently injected patients with a combination of heatkilled Streptococcus and Serratia marcescens [18-20]. Now it is understood that the bacterial products Coley injected provided the 'danger signals' that induced DCs to give efficient costimulation to both the innate and the adaptive arms of the immune system [21]. Additionally, the increased inflammation and necrotic tissue at the site of the sarcoma, where the injection of bacterial products was 


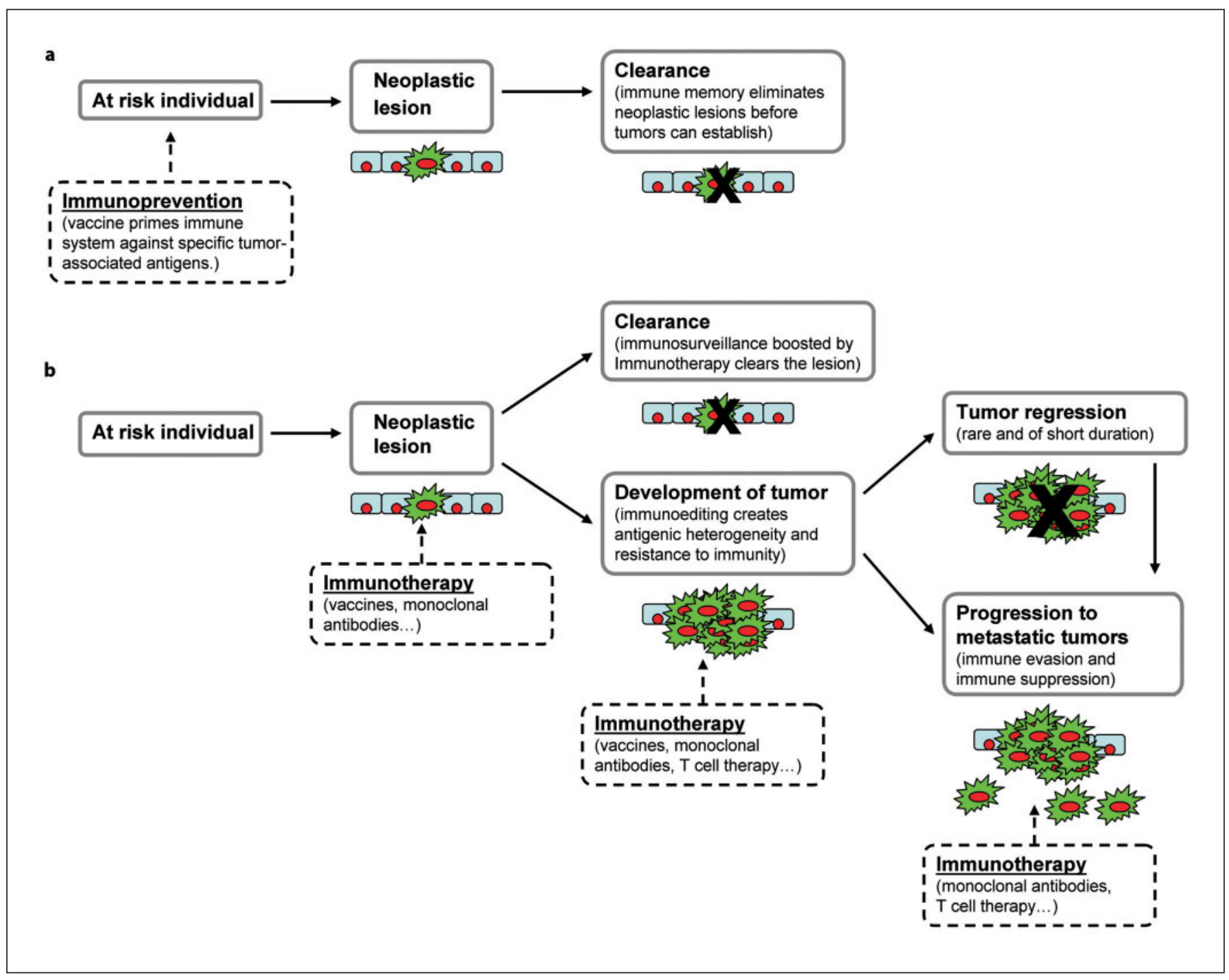

Fig. 1. The difference between immunoprevention and immunotherapy is in the timing and the expected outcome. a Immunoprevention uses a vaccine in an individual at risk for developing cancer, to generate immunologic memory that prepares the immune system to detect and eliminate future premalignant lesions. b Conversely, immunotherapy addresses the disease after it is already diagnosed. Immunotherapies can take the form of vaccines or monoclonal antibody therapies among others. Depending on when the disease is detected, immunotherapies can be given early (neoplastic lesions) or late (primary and metastatic tumors) in the disease process. Due to limitations in detecting neoplastic lesions most immunotherapies are given at later stages of disease and show success primarily in the setting of a minimal tumor burden. made, would have increased the number and efficiency of antigen-presenting cells (APCs). Without antigen presentation and strong costimulation, some tumors can progress unchecked by the immune system.

The above examples describe instances where tumor progression or tumor rejection are byproducts of the immune response activated through dangers other than the tumor itself. While one can learn a great deal from studying these processes, especially regarding the immune ef- fectors and their targets on tumor cells, only an elicited tumor-specific immune response can be turned into a therapy with a reproducible outcome. For generating the ultimate antitumor effector cells, tumor-specific antigens need to be presented on professional APCs. The most potent of these are DCs, which are being targeted in vivo or manipulated in vitro for use as adjuvants in numerous current therapies [8]. 


\section{Tumor Immunotherapy}

Several approaches to target tumors are currently being pursued that exploit the specificity of the immune system. The first among these is the vaccine approach. Traditionally vaccines have been exceptionally effective at priming the immune system to protect against infectious diseases. Based on this successful protection against infectious disease, vaccines may also be effective at priming an individual's immune system to control their own malignancies. Choosing an adjuvant and target antigen has proven challenging and success is likely to result from polyvalent approaches that utilize as many aspects of the immune response as possible. Timing is also important; the most effective vaccination against pathogens occurs before infection and this is likely to be most effective for malignancies as well [22]. Therapeutic vaccines that treat patients after diagnosis of malignant disease are currently being tested [23]. However, the immense success of the one prophylactic cancer vaccine that immunizes against human papilloma virus and protects against cervical cancer has reinforced that prevention is better than therapy during disease [24]. Additional evidence that immunologically relevant events protect against developing malignancies later in life would argue that such prophylaxis is the route to follow. One recent report from our laboratory demonstrates that bone breaks, contraceptive use, mastitis, and pelvic surgeries are protective against ovarian cancer with the hypothesis that the anti-MUC1 responses induced during those episodes provide protection from malignancies [25].

\section{Antitumor Vaccines}

When vaccinating an individual, the goal is to provide an effective immune memory response to antigen challenge. Whether the targeted antigen comes from a pathogen or is from a transformed cell, the same principles apply. There are three main questions to answer when developing a vaccine: what antigen(s) to target, what is the ideal time and route of vaccine delivery, and what adjuvant to use in order to elicit a desired type of immune response?

\section{Tumor Antigens}

When vaccinating against an infectious agent, the antigens used are foreign to the host immune system and thus are free from many of the complicating concerns of cancer antigens being self-antigens. Because malignant transformation comes from the 'host material' immune responses against many of the antigens expressed on tumors are either subject to self-tolerance or potentially could result in autoimmunity if tolerance is broken. However, there are several classes of antigens that make good potential targets for use in vaccines directed against tumors because their restricted expression or expression pattern is characteristic of tumors rather than healthy tissue, and thus not hindered by self-tolerance or prone to generate adverse autoimmune effects.

Some selected characteristics of tumor antigens that make them useful targets for immunotherapy are: (1) common expression on a variety of carcinomas thus making the vaccine more broadly applicable, (2) stable expression through different stages of tumor development so that stem cells, progenitor cells and mature tumor cells can all be targets of the elicited immune responses, and (3) indispensable for tumor survival and thus not susceptible to immunoediting [26]. Many tumor antigens identified to date have these characteristics. They belong to several categories that include products of mutated genes, viral antigens, differentially expressed antigens and tissue-restricted antigens. Most tumor antigens characterized to date are differentially expressed antigens and tissue-restricted antigens.

\section{Differentially Expressed Tumor Antigens}

Early attempts at understanding tumor immunity were based on the assumption that the immune system can only recognize molecules that are expressed in tumors as a result of many oncogenic events, and not on normal cells. However, this assumption proved incorrect and the majority of molecules identified as human tumor targets were found to have the same gene and protein sequence as the normal cells that gave rise to the tumor. The differences seen by the immune system were instead quantitative, such as antigenic overexpression, and/or qualitative, such as aberrant posttranslational modifications. We describe below three well-known tumor antigens that belong to this category and also fulfill the criteria for good vaccine candidates.

Human mucin 1 (MUC1) has been studied as a tumor antigen and target for immunotherapy for over a decade. In healthy tissues, MUC1 is expressed at low levels on the apical surface of ductal epithelial cells as a heavily glycosylated transmembrane protein. Conversely, in the majority of human adenocarcinomas, MUC1 is overexpressed and hypoglycosylated $[27,28]$.

Many patients with MUC1+ tumors have low levels of specific CTLs $[29,30]$ and low antibody titer [31, 32], and 
both types of responses have been shown to be specific for the polypeptide core of MUC1. Even though the patients have detectable tumor MUC1-specific immune responses, most succumb to their disease. As a preclinical model, we have shown the safety and immunogenicity of three different MUC1-based vaccines in the MUC1transgenic mouse [33]. In addition, we showed an important difference in the anti-MUC1 responses when MUC1 is expressed as a self-molecule as compared to the wildtype mouse where it is not endogenously expressed. We and others have attributed this difference to the hyporesponsiveness in the MUC1-specific CD4 T helper cell compartment [33-35]. A new opportunity for MUC1 tumor vaccine preclinical studies has emerged with the development of spontaneous tumor models in the MUC1transgenic mouse [36-38]. These will allow a more physiological comparison to humans concerning the effectiveness of MUC1-specific vaccines. In addition to mouse studies, we have used a MUC1 peptide with adjuvant LeIF (Leishmania braziliensis-derived protein) vaccine in nonhuman primates that was safe, tolerable, and capable of inducing an anti-MUC1 cellular immune response [39]. More recently we completed a phase I trial using a vaccine composed of the MUC1 100-amino acid core polypeptide with the adjuvant SB-AS2 (monophosphoryl A, purified saponin and an oil-water immersion) to treat pancreatic cancer patients after tumor resection [40]. This trial showed the vaccine to be safe and to have the potential of inducing MUC1-specific immune responses.

HER2/neu (also known as Erb-B2) is expressed as a $185-\mathrm{kDa}$ glycoprotein surface receptor, member of the epidermal growth factor family of tyrosine kinase receptors. HER2/neu functions in cell cycle regulation and its expression on healthy tissues are low [41]. Numerous adenocarcinomas show HER2/neu overexpression, including those of the breast, ovary, colon, prostate, and lung. HER2/neu overexpressing tumors have been characterized as being more aggressive and linked to shorter patient survival [42].

A finding that indicated the potential of HER2/neu as a vaccine candidate and target for immunotherapy was the presence of preexisting anti-HER2/neu immune responses in cancer patients with HER2/neu-overexpressing tumors. As in the case of MUC1 immunity, even though the response is too low to effectively clear the established tumor, it indicates that the adaptive immune repertoire had not been depleted of HER2/neu-specific B and $\mathrm{T}$ cells through tolerance mechanisms to self-proteins [43].

Tumor Antigens for Immunotherapy
The most notable HER2/neu-based immunotherapy is the humanized anti-HER2/neu antibody Herceptin ${ }^{\circledR}$ (trastuzumab). Originally generated and studied in mice, Herceptin is currently FDA approved as it has been shown to confer longer disease-free survival in HER2/neu+ breast cancer patients $[44,45]$. In addition to Herceptin, invoking cellular anti-HER2/neu responses has been shown to control tumor growth in spontaneous breast cancer models in HER2/neu-transgenic mice [46, 47] and breast and ovarian cancer patients [48].

Cyclin B1 was recently identified to be a tumor antigen by our group and shown to be constitutively overexpressed in the cytoplasm of tumor tissue and tumor cell lines [49]. Under normal conditions cyclin B1 is transiently expressed in the nucleus as a mediator of the G2-M phase transition in the cell cycle. Our group and others have shown cyclin B1 expression to be regulated by p53, and overexpression in transformed tissue has been associated with the deregulation of this well-studied tumor suppressor gene [50,51]. Cyclin B1 deregulation has been associated with oncogenesis as well as poor prognosis [52].

Cyclin B1 overexpression and anti-cyclin B1 immune responses have been identified in patients with various adenocarcinomas, including those of the colon, pancreas, breast and lung [49, 53-55]. Current preclinical studies on human cyclin B1 have been limited to human tissue samples and cell lines. Our group has begun preliminary work examining human cyclin B1 immune responses and mouse cyclin B1 antitumor vaccines (unpubl. data) using the p53-/- mouse model of spontaneous carcinoma [56].

Tissue-Restricted Antigens

In contrast to differentially expressed antigens, it was gradually recognized that some tumor antigens were not expressed on the normal tissue that tumors originated from. These tumor antigens are referred to as tissue-restricted antigens because their expression in healthy individuals is either restricted to fetal development, before the adaptive immune system completely matures, or restricted to immune privileged sites and not accessible to immune surveillance. As such, they make excellent vaccine targets, as previously arising tolerance and autoimmunity are less likely to be complicating factors.

Identified in 1965 [57], carcinoembryonic antigen (CEA) has been widely studied for its role as a tumor marker and tumor antigen. CEA is a $180-\mathrm{kDa}$ glycoprotein, found both at the cell surface and in a secreted form. CEA is categorized as an oncofetal antigen, expressed at

Int Arch Allergy Immunol 2007;142:179-189 
high levels in the fetal gut during development, and more recently CEA was found in some cases to be expressed at low levels in the adult colon $[58,59]$.

A clear function of CEA in healthy and transformed tissue has yet to be defined. Studies have indicated a role as an intercellular adhesion molecule $[60,61]$ and when overexpressed, an inhibitor of anoikis [62], a form of apoptosis triggered by insufficient cell-matrix contacts [63]. In addition, CEA overexpression on neoplastic tissue has a role in tumor progression and metastasis [64]. Tumor CEA has an aberrant glycosylation pattern [65, 66] and is overexpressed on a large number of adenocarcinomas, including $90 \%$ of gastrointestinal, colorectal, and pancreatic cancers, $70 \%$ of non-small-cell lung cancers, and $50 \%$ of breast cancers [67]. The tumor expression profile of CEA on a large number of different adenocarcinomas, in combination with its possible role in tumor progression and metastasis, makes CEA a promising target for immunotherapy.

CEA-transgenic mice have been used for preclinical studies of various forms of CEA-targeted immunotherapies. Vaccines using recombinant pox viral vectors (vaccinia, ALVAC, fowlpox), DCs, or anti-idiotype antibodies have been shown to generate anti-CEA-mediated protective immunity to subsequent tumor challenge [67]. The anti-CEA immune response was also demonstrated in HLA-A2:CEA double-transgenic mice [68]. Importantly, these studies showed that intrinsic tolerance to CEA could be overcome in the CEA-transgenic mice without causing any adverse autoimmune effects [69]. Following the animal studies, several human studies and phase I trials have been completed showing safety as well as induction of anti-CEA immune responses and antitumor effects [70].

The NY-ESO-1 antigen falls into a subcategory of tissue-restricted antigens, the cancer/testis antigens. Expression of these antigens is normally restricted to germ cells and trophoblasts but is also expressed on a wide variety of cancers. Over 40 antigens have been identified as cancer/testis antigens with NY-ESO-1 having been the most studied to date due to its strong tumor-specific immunostimulatory capacity [71]. Recently completed clinical studies using an NY-ESO-1 and ISCOMATRIX adjuvant vaccination strategy showed the vaccine to be well tolerated, safe, and capable of inducing potent immune responses [72], as well as possible clinical responses [73]. Currently a number of clinical trials treating various cancer types are being conducted using differing combinations of NY-ESO-1 and adjuvants [74].
In recent years there has been a trend for antitumor vaccines to include multiple tumor antigens $[75,76]$. Considering the rapid growth rate and genetic instability of growing malignancies, combining multiple antigens into a single vaccine will help to prevent development of tumor antigenic loss variants $[77,78]$. In addition to addressing tumor antigenic loss variants, other tumor escape mechanisms need to be considered. These mechanisms can include activity of $\mathrm{T}$ regulatory cells, expression of regulatory molecules, and/or production of anti-inflammatory cytokines $[79,80]$.

\section{Vaccine Design}

Currently most therapeutic vaccines use single antigens and most are chosen for their ability to elicit cytotoxic $\mathrm{T}$ cell responses [81]. There is evidence from animal studies, however, that for full tumor control involving establishment of a strong memory response, more may be needed than just an effector $T$ cell response [82]. A vaccine that can elicit a more comprehensive immune response involving both helper and cytotoxic T cells, as well as a strong antibody response, is likely to be the vaccine that can provide effective tumor control. This type of vaccine will require either multiple tumor antigens or multiple epitopes derived from the same antigen, as well as adjuvants that stimulate good innate immune responses and production of cytokines important for supporting both arms of the adaptive immune system. In our own studies of MUC1 vaccines we have favored a long peptide (100 amino acids) as antigen because it contains epitopes recognized by CTL, helper T cells $[83,84]$ and B cells [32] The use of longer peptides is now advocated by other groups as well [85].

How a vaccine is administered is another important consideration in vaccine design. We discussed above how important timing relevant to disease occurrence is likely to be in vaccination. The route of entry for antigens and associated adjuvants is equally important [86]. Traditionally, vaccines have been injected intramuscularly, regardless of the site of cancer. This is suboptimal in two very important ways. Intramuscular injection is likely to elicit systemic immunity. Cancers that occur in mucosal sites, particularly those involving mucosal epithelium might require a good mucosal immune response instead and thus mucosally administered vaccines would be a better strategy. The microenvironment of gastric and gynecologic mucosa is a tolerogenic one that adenocarcinomas evolve within, and to target them appropriately a mucosal route of administration of antigen and potent mucosal adjuvants are necessary [86]. An example of a 
successful mucosal vaccine is FLUMIST ${ }^{\mathrm{TM}}$, an intranasal vaccine against influenza. This vaccine as well as other effective vaccines against pathogens can inform cancer vaccine design. Adjuvants were mentioned several times above in connection with vaccine design. The reason is that administering antigens that do not activate APCs and induce high levels of costimulatory molecules would simply induce tolerance.

One example of a promising adjuvant is heat-labile toxin of Escherichia coli (LT). When given topically over the site of antigen injection, LT is believed to activate APCs found in the skin, Langerhans cells, which take up antigen and become potent immunostimulatory cells [87]. The topical LT adjuvant given with an influenza vaccine has shown an increase in influenza-specific immune response in elderly adults ( $>60$ years) compared to vaccine alone [88]. This finding has implications to tumor immunotherapy due to the fact that more cancers predominantly arise in the elderly.

Because of their ability to take up antigens and process them into MHC I- and MHC II-restricted peptides that can prime or boost tumor-specific CD4 and CD8 T cells, and because they can be activated to express costimulatory molecules and various important cytokines, DCs are known as 'nature's adjuvants'. DC-based vaccines use autologous DCs generated in vitro to present tumor antigens along with potent costimulation to $\mathrm{T}$ cells. Immature DCs grown in vitro are loaded with a tumor antigen of choice, most often through the process of phagocytosis that traditionally targets antigen for MHC II presentation. This is responsible for generating a tumor-specific $\mathrm{T}$ helper response. Sustained responses against tumors require CD4 $\mathrm{T}$ cell help [8]. An effective immune response against tumors needs a vigorous CD8 CTL response that requires presentation of tumor antigens in MHC I. DCs have the ability to cross-prime; antigens from the same source can be presented on both MHC I and MHC II. In vitro, DCs have been loaded with peptides that are specific to MHC I and MHC II by using specific amino acid sequences [89]. This method is rather inefficient and is limited by the number of peptides available. However, DCs can be induced to cross present antigens depending on the presence of proinflammatory cytokines and CD40 ligation [8]. Targeting of the endocytic receptor DEC-205 with an antigen-antibody conjugate has also capitalized on this pathway to target a more complete immune response [90].

Tumor Antigens for Immunotherapy

\section{Therapy with Monoclonal Antibodies}

The use of humanized or chimeric monoclonal antibodies has been particularly successful against specific types of cancers. Antibody binding to tumor cells can cause direct killing through antibody-dependent cellular cytotoxicity, complement-mediated lysis, or through inhibition of target cell proliferation [91]. As discussed earlier, breast cancers that overexpress HER2/neu are susceptible to the humanized antibody Herceptin [92].

Monoclonal antibodies to tumor antigens can also deliver a chemotherapeutic agent such as a radiolabeled isotope. Monoclonal antibodies to CEA linked to both yttrium-90 and iodine-131 have been used with limited efficacy $[93,94]$. However, this approach has been very successful with B cell lymphomas treated with a monoclonal antibody to CD20 linked to iodine-131 (Bexxar ${ }^{\circledR}$ ) $[95,96]$. Administration of the same chimeric antibody, rituximab, with a chemotherapeutic cocktail containing cyclophosphamide, doxorubicin, vincristine, and prednisone prolongs event-free survival in patients with B cell lymphoma [97]. Rituximab has been successful in treating a number of B cell-mediated lymphomas and is now also approved for use in rheumatoid arthritis.

\section{Preclinical Models}

The most commonly used animal models in tumor immunology research are mice. Since the majority of tumor-associated antigens are derived from self-antigens, it is important to test antitumor vaccines in mice that also express the tumor antigen as a self-antigen. This need led to the engineering of mice expressing human tumor antigens as transgenes, for example MUC1- and CEA-transgenic mice $[69,98]$. Using the transgenic mice one can answer questions about the efficacy of the therapy, endogenous immune tolerance mechanisms, as well as possible autoimmune damage to healthy tissue.

Until recently, the majority of studies assessing the effects of in vivo tumor immunotherapy involved postvaccination tumor challenge by injection of a cultured tumor cell line. Although this has demonstrated tumor-associated antigen-specific protection, these models do not represent human disease. To better mimic the interaction of the innate or vaccine-elicited immune response with the slow progression of carcinoma that occurs in humans, spontaneous tumor models have been developed [2, 3, 99-102]. One of the newest is a model based on a conditionally expressed mutant of Kras [103]. The fact that

Int Arch Allergy Immunol 2007;142:179-189 
Kras is an oncogene that is commonly mutated in human tumors makes the model very attractive to study neoplastic growth and the immune responses right from the start of cellular transformation. More specifically, spontaneous tumor models allow one to follow the appearance and role of specific tumor antigens in oncogenesis and disease and the immune response against it.

\section{Conclusion}

Each cancer can be as unique as the patient that suffers from it but there are also antigenic similarities that can be exploited for immunotherapy. As the individual's immune system and neoplasm coexist for a prolonged period of tumor development, each exerts influence on the other. Two promising areas of tumor immunotherapy are vaccines and monoclonal antibody-based therapies. An important difference between these two therapies is that monoclonal antibodies are limited to the presence of disease, whereas tumor antigen-based vaccines can serve either as a tumor immunotherapy (concurrent with disease) or as an immunoprevention treatment (for individuals at high risk for cancer). The best-case scenario would be to prevent disease from occurring, by using prophylactic vaccination. This has worked exceptionally well in the case of infectious disease. Development of many technologies that identify early disease and/or individuals at high risk for disease, combined with the improved understanding of the requirements for greater efficacy and safety of antitumor immune responses, has brought cancer immunoprophylaxis into the mainstream of cancer prevention efforts.

\section{References}

1 Dunn GP, Old LJ, Schreiber RD: The three Es of cancer immunoediting. Annu Rev Immunol 2004;22:329-360.

- 2 Hingorani SR, Petricoin EF, Maitra A, Rajapakse V, King C, Jacobetz MA, Ross S, Conrads TP, Veenstra TD, Hitt BA, Kawaguchi Y, Johann D, Liotta LA, Crawford HC, Putt ME, Jacks T, Wright CV, Hruban RH, Lowy AM, Tuveson DA: Preinvasive and invasive ductal pancreatic cancer and its early detection in the mouse. Cancer Cell 2003;4:437-450.

- 3 Dinulescu DM, Ince TA, Quade BJ, Shafer SA, Crowley D, Jacks T: Role of K-ras and Pten in the development of mouse models of endometriosis and endometrioid ovarian cancer. Nat Med 2005;11:63-70.

$\checkmark 4$ Schmielau J, Finn OJ: Activated granulocytes and granulocyte-derived hydrogen peroxide are the underlying mechanism of suppression of T-cell function in advanced cancer patients. Cancer Res 2001;61:47564760.

5 Paci E, Ponti A, Zappa M, Patriarca S, Falini P, Delmastro G, Bianchi S, Sapino A, Vezzosi V, Senore C, Crocetti E, Frigerio A, Zanetti R, Del Turco MR, Segnan N: Early diagnosis, not differential treatment, explains better survival in service screening. Eur J Cancer 2005;41:2728-2734.

-6 Edwards BK, Howe HL, Ries LA, Thun MJ, Rosenberg HM, Yancik R, Wingo PA, Jemal A, Feigal EG: Annual report to the nation on the status of cancer, 1973-1999, featuring implications of age and aging on U.S. cancer burden. Cancer 2002;94:2766-2792.
7 Villa LL, Costa RL, Petta CA, Andrade RP, Ault KA, Giuliano AR, Wheeler CM, Koutsky LA, Malm C, Lehtinen M, Skjeldestad FE, Olsson SE, Steinwall M, Brown DR, Kurman RJ, Ronnett BM, Stoler MH, Ferenczy A, Harper DM, Tamms GM, Yu J, Lupinacci L, Railkar R, Taddeo FJ, Jansen KU, Esser MT, Sings HL, Saah AJ, Barr E: Prophylactic quadrivalent human papillomavirus (types $6,11,16$, and 18) L1 virus-like particle vaccine in young women: a randomised doubleblind placebo-controlled multicentre phase II efficacy trial. Lancet Oncol 2005;6:271278.

8 Banchereau J, Palucka AK: Dendritic cells as therapeutic vaccines against cancer. Nat Rev Immunol 2005;5:296-306.

-9 Crowe NY, Coquet JM, Berzins SP, Kyparissoudis K, Keating R, Pellicci DG, Hayakawa Y, Godfrey DI, Smyth MJ: Differential antitumor immunity mediated by NKT cell subsets in vivo. J Exp Med 2005;202:12791288.

10 Fernandez NC, Lozier A, Flament C, Ricciardi-Castagnoli P, Bellet D, Suter M, Perricaudet M, Tursz T, Maraskovsky E, Zitvogel L: Dendritic cells directly trigger NK cell functions: cross-talk relevant in innate antitumor immune responses in vivo. Nat Med 1999;5:405-411.

11 Lin EY, Nguyen AV, Russell RG, Pollard JW: Colony-stimulating factor 1 promotes progression of mammary tumors to malignancy. J Exp Med 2001;193:727-740.
12 Coussens LM, Raymond WW, Bergers G, Laig-Webster M, Behrendtsen O, Werb Z, Caughey GH, Hanahan D: Inflammatory mast cells up-regulate angiogenesis during squamous epithelial carcinogenesis. Genes Dev 1999;13:1382-1397.

13 Bergers G, Brekken R, McMahon G, Vu TH, Itoh T, Tamaki K, Tanzawa K, Thorpe P, Itohara S, Werb Z, Hanahan D: Matrix metalloproteinase- 9 triggers the angiogenic switch during carcinogenesis. Nat Cell Biol 2000;2: 737-744.

14 Pagano JS, Blaser M, Buendia MA, Damania B, Khalili K, Raab-Traub N, Roizman B: Infectious agents and cancer: criteria for a causal relation. Semin Cancer Biol 2004; 14 : 453-471.

15 de Visser KE, Eichten A, Coussens LM: Paradoxical roles of the immune system during cancer development. Nat Rev Cancer 2006;6: 24-37.

16 Dannenberg AJ, Subbaramaiah K: Targeting cyclooxygenase-2 in human neoplasia: rationale and promise. Cancer Cell 2003;4:431436.

17 Herr HW, Schwalb DM, Zhang ZF, Sogani PC, Fair WR, Whitmore WF Jr, Oettgen HF: Intravesical bacillus Calmette-Guerin therapy prevents tumor progression and death from superficial bladder cancer: ten-year follow-up of a prospective randomized trial. J Clin Oncol 1995;13:1404-1408.

18 Bickels J, Kollender Y, Merinsky O, Meller I: Coley's toxin: historical perspective. Isr Med Assoc J 2002;4:471-472.

19 Hobohm U: Fever and cancer in perspective. Cancer Immunol Immunother 2001;50:391396. 
20 Wiemann B, Starnes CO: Coley's toxins, tumor necrosis factor and cancer research: a historical perspective. Pharmacol Ther 1994; 64:529-564.

-21 Matzinger P: An innate sense of danger. Ann NY Acad Sci 2002;961:341-342.

-22 Finn OJ, Forni G: Prophylactic cancer vaccines. Curr Opin Immunol 2002;14:172177.

-23 Carbone DP, Ciernik IF, Kelley MJ, Smith MC, Nadaf S, Kavanaugh D, Maher VE, Stipanov M, Contois D, Johnson BE, Pendleton CD, Seifert B, Carter C, Read EJ, Greenblatt J, Top LE, Kelsey MI, Minna JD, Berzofsky JA: Immunization with mutant p53- and Kras-derived peptides in cancer patients: immune response and clinical outcome. J Clin Oncol 2005;23:5099-5107.

-24 Harper DM, Franco EL, Wheeler CM, Moscicki AB, Romanowski B, Roteli-Martins CM, Jenkins D, Schuind A, Costa Clemens SA, Dubin G: Sustained efficacy up to 4.5 years of a bivalent L1 virus-like particle vaccine against human papillomavirus types 16 and 18: follow-up from a randomised control trial. Lancet 2006;367:1247-1255.

-25 Cramer DW, Titus-Ernstoff L, McKolanis JR, Welch WR, Vitonis AF, Berkowitz RS, Finn OJ: Conditions associated with antibodies against the tumor-associated antigen MUC1 and their relationship to risk for ovarian cancer. Cancer Epidemiol Biomarkers Prev 2005; 14:1125-1131.

-26 Dunn GP, Old LJ, Schreiber RD: The immunobiology of cancer immunosurveillance and immunoediting. Immunity 2004;21: 137.

-27 Huang L, Chen D, Liu D, Yin L, Kharbanda S, Kufe D: MUC1 oncoprotein blocks glycogen synthase kinase 3beta-mediated phosphorylation and degradation of betacatenin. Cancer Res 2005;65:10413-10422.

28 Vlad AM, Finn OJ: Glycoprotein tumor antigens for immunotherapy of breast cancer. Breast Dis 2004;20:73-79.

29 Jerome KR, Domenech N, Finn OJ: Tumorspecific cytotoxic $T$ cell clones from patients with breast and pancreatic adenocarcinoma recognize EBV-immortalized B cells transfected with polymorphic epithelial mucin complementary DNA. J Immunol 1993;151: 1654-1662.

>30 Ioannides CG, Fisk B, Jerome KR, Irimura T, Wharton JT, Finn OJ: Cytotoxic T cells from ovarian malignant tumors can recognize polymorphic epithelial mucin core peptides. J Immunol 1993;151:3693-3703.

-31 Kotera Y, Fontenot JD, Pecher G, Metzgar RS, Finn OJ: Humoral immunity against a tandem repeat epitope of human mucin MUC-1 in sera from breast, pancreatic, and colon cancer patients. Cancer Res 1994;54: 2856-2860.
32 Gourevitch MM, von Mensdorff-Pouilly S, Litvinov SV, Kenemans P, van Kamp GJ, Verstraeten AA, Hilgers J: Polymorphic epithelial mucin (MUC-1)-containing circulating immune complexes in carcinoma patients. Br J Cancer 1995;72:934-938.

33 Soares MM, Mehta V, Finn OJ: Three different vaccines based on the 140-amino acid MUC1 peptide with seven tandemly repeated tumor-specific epitopes elicit distinct immune effector mechanisms in wild-type versus MUC1-transgenic mice with different potential for tumor rejection. J Immunol 2001;166:6555-6563.

34 Tanaka Y, Koido S, Ohana M, Liu C, Gong J: Induction of impaired antitumor immunity by fusion of MHC class II-deficient dendritic cells with tumor cells. J Immunol 2005; 174:1274-1280.

35 Tempero RM, VanLith ML, Morikane K, Rowse GJ, Gendler SJ, Hollingsworth MA: CD4+ Lymphocytes provide MUC1-specific tumor immunity in vivo that is undetectable in vitro and is absent in MUC1 transgenic mice. J Immunol 1998;161:5500-5506.

\$6 Mukherjee P, Ginardi AR, Madsen CS, Sterner CJ, Adriance MC, Tevethia MJ, Gendler SJ: Mice with spontaneous pancreatic cancer naturally develop MUC-1-specific CTLs that eradicate tumors when adoptively transferred. J Immunol 2000;165:34513460 .

37 Mukherjee P, Tinder TL, Basu GD, Pathangey LB, Chen L, Gendler SJ: Therapeutic efficacy of MUC1-specific cytotoxic T lymphocytes and CD137 co-stimulation in a spontaneous breast cancer model. Breast Dis 2004;20:53-63.

38 Chen D, Xia J, Tanaka Y, Chen H, Koido S, Wernet O, Mukherjee P, Gendler SJ, Kufe D, Gong J: Immunotherapy of spontaneous mammary carcinoma with fusions of dendritic cells and mucin 1-positive carcinoma cells. Immunology 2003;109:300-307.

39 Barratt-Boyes SM, Vlad A, Finn OJ: Immunization of chimpanzees with tumor antigen MUC1 mucin tandem repeat peptide elicits both helper and cytotoxic T-cell responses. Clin Cancer Res 1999;5:1918-1924.

40 Ramanathan RK, Lee KM, McKolanis J, Hitbold E, Schraut W, Moser AJ, Warnick E, Whiteside T, Osborne J, Kim H, Day R, Troetschel M, Finn OJ: Phase I study of a MUC1 vaccine composed of different doses of MUC1 peptide with SB-AS2 adjuvant in resected and locally advanced pancreatic cancer. Cancer Immunol Immunother 2005; $54: 254$.

41 Yang G, Cai KQ, Thompson-Lanza JA, Bast RC Jr, Liu J: Inhibition of breast and ovarian tumor growth through multiple signaling pathways by using retrovirus-mediated small interfering RNA against Her-2/neu gene expression. J Biol Chem 2004;279: 4339-4345.
42 Emens LA: Trastuzumab: targeted therapy for the management of HER-2/neu-overexpressing metastatic breast cancer. Am J Ther 2005; 12:243-253.

43 Disis ML, Knutson KL, Schiffman K, Rinn K, McNeel DG: Pre-existent immunity to the HER-2/neu oncogenic protein in patients with HER-2/neu overexpressing breast and ovarian cancer. Breast Cancer Res Treat 2000;62:245

44 Piccart-Gebhart MJ, Procter M, LeylandJones B, Goldhirsch A, Untch M, Smith I, Gianni L, Baselga J, Bell R, Jackisch C, Cameron D, Dowsett M, Barrios CH, Steger G, Huang C-S, Andersson M, Inbar M, Lichinitser M, Lang I, Nitz U, Iwata $H$, Thomssen C, Lohrisch C, Suter TM, Ruschoff J, Suto T, Greatorex V, Ward C, Straehle C, McFadden E, Dolci MS, Gelber RD; Herceptin Adjuvant Trial Study Team: Trastuzumab after adjuvant chemotherapy in HER2-positive breast cancer. N Engl J Med 2005;353:1659-1672.

45 Romond EH, Perez EA, Bryant J, Suman VJ, Geyer CE Jr, Davidson NE, Tan-Chiu E, Martino S, Paik S, Kaufman PA, Swain SM, Pisansky TM, Fehrenbacher L, Kutteh LA, Vogel VG, Visscher DW, Yothers G, Jenkins RB, Brown AM, Dakhil SR, Mamounas EP, Lingle WL, Klein PM, Ingle JN, Wolmark N: Trastuzumab plus adjuvant chemotherapy for operable HER2-positive breast cancer. N Engl J Med 2005;353:1673-1684.

46 Manjili MH, Wang X-Y, Chen X, Martin T, Repasky EA, Henderson R, Subjeck JR: HSP110-HER2/neu chaperone complex vaccine induces protective immunity against spontaneous mammary tumors in HER-2/ neu transgenic mice. J Immunol 2003;171: 4054-4061.

47 Park JM, Terabe M, Sakai Y, Munasinghe J, Forni G, Morris JC, Berzofsky JA: Early role of CD4+ Th1 cells and antibodies in HER-2 adenovirus vaccine protection against autochthonous mammary carcinomas. J Immunol 2005; 174:4228-4236.

$\checkmark 48$ Disis ML, Schiffman K, Guthrie K, Salazar LG, Knutson KL, Goodell V, dela Rosa C, Cheever MA: Effect of dose on immune response in patients vaccinated with an HER$2 /$ neu intracellular domain protein-based vaccine. J Clin Oncol 2004;22:1916-1925.

49 Kao H, Marto JA, Hoffmann TK, Shabanowitz J, Finkelstein SD, Whiteside TL, Hunt DF, Finn OJ: Identification of cyclin B1 as a shared human epithelial tumor-associated antigen recognized by $\mathrm{T}$ cells. J Exp Med 2001;194:1313-1324.

50 Yu M, Zhan Q, Finn OJ: Immune recognition of cyclin B1 as a tumor antigen is a result of its overexpression in human tumors that is caused by non-functional p53. Mol Immunol 2002;38:981. 
51 Innocente SA, Abrahamson JLA, Cogswell JP, Lee JM: p53 regulates a G2 checkpoint through cyclin B1. Proc Natl Acad Sci USA 1999;96:2147-2152.

-52 Soria J-C, Jang SJ, Khuri FR, Hassan K, Liu D, Hong WK, Mao L: Overexpression of cyclin B1 in early-stage non-small cell lung cancer and its clinical implication. Cancer Res 2000;60:4000-4004.

53 Singhal S, Vachani A, Antin-Ozerkis D, Kaiser LR, Albelda SM: Prognostic implications of cell cycle, apoptosis, and angiogenesis biomarkers in non-small cell lung cancer: a review. Clin Cancer Res 2005;11:3974-3986.

54 Suzuki H, Graziano DF, McKolanis J, Finn OJ: $\mathrm{T}$ cell-dependent antibody responses against aberrantly expressed cyclin B1 protein in patients with cancer and premalignant disease. Clin Cancer Res 2005;11:15211526.

55 Gorczyca W, Sarode V, Juan G, Melamed MR, Darzynkiewicz Z: Laser scanning cytometric analysis of cyclin B1 in primary human malignancies. Mod Pathol 1997;10: 457-462.

-56 Donehower LA, Harvey M, Slagle BL, McArthur MJ, Montgomery CA Jr, Butel JS, Bradley A: Mice deficient for p53 are developmentally normal but susceptible to spontaneous tumours. Nature 1992;356:215-221.

57 Gold P, Freedman SO: Specific carcinoembryonic antigens of the human digestive system. J Exp Med 1965;122:467-481.

-58 Nap M, Mollgard K, Burtin P, Fleuren GJ: Immunohistochemistry of carcino-embryonic antigen in the embryo, fetus and adult. Tumour Biol 1988;9:145-153.

59 Wagener C, Hain F, Fodisch HJ, Breuer H: Localisation of carcinoembryonic antigen in embryonic and fetal human tissues. Histochemistry 1983;78:1-9.

60 Benchimol S, Fuks A, Jothy S, Beauchemin N, Shirota K, Stanners CP: Carcinoembryonic antigen, a human tumor marker, functions as an intercellular adhesion molecule. Cell 1989;57:327.

-61 Oikawa S, Inuzuka C, Kuroki M, Matsuoka Y, Kosaki G, Nakazato H: Cell adhesion activity of non-specific cross-reacting antigen (NCA) and carcinoembryonic antigen (CEA) expressed on $\mathrm{CHO}$ cell surface: homophilic and heterophilic adhesion. Biochem Biophys Res Commun 1989;164:39.

-62 Ordonez C, Screaton RA, Ilantzis C, Stanners CP: Human carcinoembryonic antigen functions as a general inhibitor of anoikis. Cancer Res 2000;60:3419-3424.

-63 Frisch SM, Screaton RA: Anoikis mechanisms. Curr Opin Cell Biol 2001;13:555.

-64 Blumenthal RD, Hansen HJ, Goldenberg DM: Inhibition of adhesion, invasion, and metastasis by antibodies targeting CEACAM6 (NCA-90) and CEACAM5 (carcinoembryonic antigen). Cancer Res 2005; 65:8809-8817.
65 van Gisbergen KPJM, Aarnoudse CA, Meijer GA, Geijtenbeek TBH, van Kooyk Y: Dendritic cells recognize tumor-specific glycosylation of carcinoembryonic antigen on colorectal cancer cells through dendritic cell-specific intercellular adhesion molecule-3-grabbing nonintegrin. Cancer Res 2005;65:5935-5944

-66 Garcia M, Seigner C, Bastid C, Choux R, Payan $\mathrm{MJ}$, Reggio $\mathrm{H}$ : Carcinoembryonic antigen has a different molecular weight in normal colon and in cancer cells due to N-glycosylation differences. Cancer Res 1991;51:5679_ 5686.

67 Sarobe P, Huarte E, Lasarte JJ, Borras-Cuesta F: Carcinoembryonic antigen as a target to induce anti-tumor immune responses. Curr Cancer Drug Targets 2004;4:443-454.

68 Berinstein NL: Carcinoembryonic antigen as a target for therapeutic anticancer vaccines: a review. J Clin Oncol 2002;20:21972207.

69 Hance KW, Zeytin HE, Greiner JW: Mouse models expressing human carcinoembryonic antigen (CEA) as a transgene: evaluation of CEA-based cancer vaccines. Mutat Res 2005;576:132.

70 Marshall JL, Gulley JL, Arlen PM, Beetham PK, Tsang KY, Slack R, Hodge JW, Doren S, Grosenbach DW, Hwang J, Fox E, Odogwu L, Park S, Panicali D, Schlom J: Phase I study of sequential vaccinations with fowlpoxCEA(6D)-TRICOM alone and sequentially with vaccinia-CEA(6D)-TRICOM, with and without granulocyte-macrophage colonystimulating factor, in patients with carcinoembryonic antigen-expressing carcinomas. J Clin Oncol 2005;23:720-731.

71 Simpson AJG, Caballero OL, Jungbluth A, Chen Y-T, Old LJ: Cancer/testis antigens, gametogenesis and cancer. Nat Rev Cancer 2005;5:615.

72 Chen Q, Jackson H, Parente P, Luke T, Rizkalla M, Tai TY, Zhu H-C, Mifsud NA, Dimopoulos N, Masterman K-A, Hopkins W, Goldie H, Maraskovsky E, Green S, Miloradovic L, McCluskey J, Old LJ, Davis ID, Cebon J, Chen W: Immunodominant CD4+ responses identified in a patient vaccinated with full-length NY-ESO-1 formulated with ISCOMATRIX adjuvant. Proc Natl Acad Sci USA 2004;101:9363-9368.

73 Davis ID, Chen W, Jackson H, Parente P, Shackleton M, Hopkins W, Chen Q, Dimopoulos N, Luke T, Murphy R, Scott AM, Maraskovsky E, McArthur G, MacGregor D, Sturrock S, Tai TY, Green S, Cuthbertson A, Maher D, Miloradovic L, Mitchell SV, Ritter G, Jungbluth AA, Chen Y-T, Gnjatic S, Hoffman EW, Old LJ, Cebon JS: Recombinant NY-ESO-1 protein with ISCOMATRIX adjuvant induces broad integrated antibody and CD4+ and CD8+ T cell responses in humans. Proc Natl Acad Sci USA 2004;101: 10697-10702.
74 Nicholaou T, Ebert L, Davis ID, Robson N, Klein O, Maraskovsky E, Chen W, Cebon J: Directions in the immune targeting of cancer: lessons learned from the cancer-testis Ag NY-ESO-1. Immunol Cell Biol 2006;84: 303-317.

75 Valmori D, Dutoit V, Ayyoub M, Rimoldi D, Guillaume P, Lienard D, Lejeune F, Cerottini JC, Romero P, Speiser DE: Simultaneous CD8+ T cell responses to multiple tumor antigen epitopes in a multipeptide melanoma vaccine. Cancer Immun 2003;28:15.

76 Fuessel S, Meye A, Schmitz M, Zastrow S, Linné C, Richter K, Löbel B, Hakenberg OW, Hoelig K, Rieber EP, Wirth MP: Vaccination of hormone-refractory prostate cancer patients with peptide cocktail-loaded dendritic cells: results of a phase I clinical trial. Prostate 2006;66:811-821.

77 Manjili M, Arnouk H, Knutson K, Kmieciak M, Disis M, Subjeck J, Kazim A: Emergence of immune escape variant of mammary tumors that has distinct proteomic profile and a reduced ability to induce 'danger signals'. Breast Cancer Res Treat 2006;96:233.

78 Gajewski TF, Fallarino F, Ashikari A, Sherman M: Immunization of HLA-A2+ melanoma patients with MAGE-3 or MelanA peptide-pulsed autologous peripheral blood mononuclear cells plus recombinant human interleukin 12. Clin Cancer Res 2001;7:895s901s.

79 Laheru DA, Pardoll DM, Jaffee EM: Genes to vaccines for immunotherapy: how the molecular biology revolution has influenced cancer immunology. Mol Cancer Ther 2005; 4:1645-1652.

$>80$ Gajewski TF, Meng Y, Harlin H: Immune suppression in the tumor microenvironment. J Immunother 2006;29:233-240.

81 Rosenberg SA, Yang JC, Restifo NP: Cancer immunotherapy: moving beyond current vaccines. Nat Med 2004;10:909-915.

-82 Rosenberg SA, Sherry RM, Morton KE, Scharfman WJ, Yang JC, Topalian SL, Royal RE, Kammula U, Restifo NP, Hughes MS, Schwartzentruber D, Berman DM, Schwarz SL, Ngo LT, Mavroukakis SA, White DE, Steinberg SM: Tumor progression can occur despite the induction of very high levels of self/tumor antigen-specific CD8+ T cells in patients with melanoma. J Immunol 2005; 175:6169-6176.

83 Hiltbold EM, Ciborowski P, Finn OJ: Naturally processed class II epitope from the tumor antigen $\mathrm{MUC1}$ primes human $\mathrm{CD} 4+\mathrm{T}$ cells. Cancer Res 1998;58:5066-5070.

$>84$ Hiltbold EM, Alter MD, Ciborowski P, Finn OJ: Presentation of MUC1 tumor antigen by class I MHC and CTL function correlate with the glycosylation state of the protein taken up by dendritic cells. Cell Immunol 1999;194:143. 
-85 Vambutas A, DeVoti J, Nouri M, Drijfhout JW, Lipford GB, Bonagura VR, van der Burg $\mathrm{SH}$, Melief CJM: Therapeutic vaccination with papillomavirus E6 and E7 long peptides results in the control of both established virus-induced lesions and latently infected sites in a pre-clinical cottontail rabbit papillomavirus model. Vaccine 2005;23:5271.

-86 Holmgren J, Czerkinsky C: Mucosal immunity and vaccines. Nat Med 2005;11(4 suppl): S45-S53.

-87 Glenn GM, Taylor DN, Li X, Frankel S, Montemarano A, Alving CR: Transcutaneous immunization: a human vaccine delivery strategy using a patch. Nat Med 2000;6: 1403-1406.

$>88$ Frech SA, Kenney RT, Spyr CA, Lazar H, Viret J-F, Herzog C, Gluck R, Glenn GM: Improved immune responses to influenza vaccination in the elderly using an immunostimulant patch. Vaccine 2005;23:946.

-89 Parmiani G, Castelli C, Dalerba P, Mortarini R, Rivoltini L, Marincola FM, Anichini A: Cancer immunotherapy with peptide-based vaccines: What have we achieved? Where are we going? J Natl Cancer Inst 2002;94:805818.

90 Trumpfheller C, Finke JS, Lopez CB, Moran TM, Moltedo B, Soares H, Huang Y, Schlesinger SJ, Park CG, Nussenzweig MC, Granelli-Piperno A, Steinman RM: Intensified and protective CD4+ T cell immunity in mice with anti-dendritic cell HIV gag fusion antibody vaccine. J Exp Med 2006;203:607617.

-91 Golay J, Zaffaroni L, Vaccari T, Lazzari M, Borleri GM, Bernasconi S, Tedesco F, Rambaldi $\mathrm{A}$, Introna $\mathrm{M}$ : Biologic response of $\mathrm{B}$ lymphoma cells to anti-CD20 monoclonal antibody rituximab in vitro: CD55 and CD59 regulate complement-mediated cell lysis. Blood 2000;95:3900-3908.
92 Goldenberg MM: Trastuzumab, a recombinant DNA-derived humanized monoclonal antibody, a novel agent for the treatment of metastatic breast cancer. Clin Ther 1999;21: 309-318.

$>93$ Sharkey RM, Hajjar G, Yeldell D, Brenner A, Burton J, Rubin A, Goldenberg DM: A phase I trial combining high-dose ${ }^{90}$ Y-labeled humanized anti-CEA monoclonal antibody with doxorubicin and peripheral blood stem cell rescue in advanced medullary thyroid cancer. J Nucl Med 2005;46:620-633.

94 Chatal JF, Campion L, Kraeber-Bodere F, Bardet S, Vuillez JP, Charbonnel B, Rohmer V, Chang CH, Sharkey RM, Goldenberg DM, Barbet J: Survival improvement in patients with medullary thyroid carcinoma who undergo pretargeted anti-carcinoembryonicantigen radioimmunotherapy: a collaborative study with the French Endocrine Tumor Group. J Clin Oncol 2006;24:1705-1711.

95 Horning SJ, Younes A, Jain V, Kroll S, Lucas J, Podoloff D, Goris M: Efficacy and safety of tositumomab and iodine-131 tositumomab (Bexxar) in B-cell lymphoma, progressive after rituximab. J Clin Oncol 2005;23:712719.

$\$ 96$ Maloney DG, Liles TM, Czerwinski DK, Waldichuk C, Rosenberg J, Grillo-Lopez A, Levy R: Phase I clinical trial using escalating single-dose infusion of chimeric anti-CD20 monoclonal antibody (IDEC-C2B8) in patients with recurrent B-cell lymphoma. Blood 1994;84:2457-2466.
97 Coiffier B, Lepage E, Briere J, Herbrecht R, Tilly H, Bouabdallah R, Morel P, Van Den Neste E, Salles G, Gaulard P, Reyes F, Lederlin P, Gisselbrecht C: CHOP chemotherapy plus rituximab compared with $\mathrm{CHOP}$ alone in elderly patients with diffuse largeB-cell lymphoma. N Engl J Med 2002;346: 235-242.

98 Rowse GJ, Tempero RM, VanLith ML, Hollingsworth MA, Gendler SJ: Tolerance and immunity to MUC1 in a human MUC1 transgenic murine model. Cancer Res 1998; 58:315-321.

99 Aguirre AJ, Bardeesy N, Sinha M, Lopez L, Tuveson DA, Horner J, Redston MS, DePinho RA: Activated Kras and Ink4a/Arf deficiency cooperate to produce metastatic pancreatic ductal adenocarcinoma. Genes Dev 2003;17:3112-3126.

100 Amundadottir LT, Johnson MD, Merlino G, Smith GH, Dickson RB: Synergistic interaction of transforming growth factor alpha and c-myc in mouse mammary and salivary gland tumorigenesis. Cell Growth Differ 1995;6:737-748.

101 Greenberg NM, DeMayo F, Finegold MJ, Medina D, Tilley WD, Aspinall JO, Cunha GR, Donjacour AA, Matusik RJ, Rosen JM: Prostate cancer in a transgenic mouse. Proc Natl Acad Sci USA 1995;92:3439-3443.

102 Tevethia MJ, Bonneau RH, Griffith JW, Mylin L: A simian virus 40 large T-antigen segment containing amino acids 1 to 127 and expressed under the control of the rat elastase-1 promoter produces pancreatic acinar carcinomas in transgenic mice. J Virol 1997;71:8157-8166.

103 Jackson EL, Willis N, Mercer K, Bronson RT, Crowley D, Montoya R, Jacks T, Tuveson DA: Analysis of lung tumor initiation and progression using conditional expression of oncogenic K-ras. Genes Dev 2001; 15:3243-3248. 